\title{
AN ANALYSIS OF STUDENTS' DIFFICULTIES IN COMPREHENDING DESCRIPTIVE TEXT
}

\author{
Rafika Nurhidayah \\ Sekolah Tinggi Bahasa Asing (STBA) Pontianak \\ rafikanurhidayah40@gmail.com
}

Submitted: 2020-11-19

Accepted: 2021-11-16

\begin{abstract}
This research was designed to investigate the difficulties faced by the second-grade students' in comprehending descriptive text in SMPN 01 Sungai Raya Kabupaten Kubu Raya. A descriptive research design was used as the method of this study. The data was collected through a measurement test in the form of multiple-choice consisted of twenty questions as the technique to collect the data. To analyse the data, the researcher used the formula for students' mean score and students' percentage of right and wrong answers. This research was focused on five aspects in reading comprehension namely main idea, detailed information, vocabulary, inference and reference. From the aspects that were being mentioned, the findings of the study revealed that the percentage of the students mean score of reading comprehension of descriptive text is categorized as poor. The result of the study shows that the difficulties faced by the students are in terms of understanding main idea, vocabulary and reference.
\end{abstract}

Keywords: Students' Difficulties; Reading Comprehension; Descriptive Text

\section{INTRODUCTION}

English is one of the most widely recognized languages in the world, and it is used in almost every country to facilitate communication between countries with diverse cultures and backgrounds. Therefore, the Indonesian government has made English one of the subjects taught as a foreign language from kindergarten to university and even being taught to elementary school students as a local content. (Prihatini, 2020). Listening, speaking, reading, and writing are the four skills that must be mastered when learning English (Harmer, 2007). However, many intellectuals have emphasized the importance of reading in the school setting. It is one of the most important ways to obtain information, particularly for educational purposes (Jarrah and Salina, 2018). According to Palani (2012), effective reading is the most important avenue of effective learning, and academic success is highly dependent on successful reading.

Grabe (as cited in Perangin-angin, 2013), states that reading is the ability to draw meaning from the printed page and interpret this information appropriately. In other words, the readers are trying to get all the detailed information from the text they read. Moreover, based on Ismail, Syahruzah and Basuki (2017), for most learners, it is the most important skill to master in order to succeed not only in learning English, but also in learning in any content class where reading in English is required. Learners will 
make more progress and develop in all areas of learning if their reading skills are improved. It is an active process which consists of recognition and comprehension skill.

There are a number of specific issues that must be addressed when teaching and learning reading skills. This includes issues with a limited vocabulary, issues in the academic field, and issues with mastering English in general. Hence, more emphasis should be placed on reading comprehension. Comprehension is the goal of reading because it is considered as a primary aspect of reading. As claimed by Prado \& Plourd (2005), comprehension is the interaction among word identification, prior knowledge, comprehension strategies, and engagement. For the students who have never learned English, they will find it difficult when they have to find the information from the text they read. Students are often required to make connections with what is being read to their own lives and experiences to understand what is being read. Moreover, they also have to learn the aspects of reading comprehension such as main idea, detail information, vocabulary, inference, and reference.

According to Brown (2003), reading comprehension is the construction of the meaning of a written the thought of a reciprocal interchange of ideas between the reader and the message in the particular text. It is the ability to read the text, process it, and understand its meaning. Furthermore, McNamara (2007) stated that reading comprehension is a product of complex interactions between the properties of the text and what readers bring to the reading situation. It can be concluded that reading comprehension is an interpretive process making the interaction between the author's ideas and the readers' ideas they have in their mind. Therefore, to make the students be able to understand and get information from the whole text given is the goal of reading comprehension.

One of the text types that the students in junior high school have to read is descriptive text. The descriptive text is a material in reading skill which belongs to a kind of text that teach and learn in junior high school level. Descriptive text is a text that describes the features of someone, something or certain place (Wardiman et al, 2008). Its function is to describe what kind of objects or living things that are describing, it could be the appearance, smell, sound or even texture. The particular person or object is described in detail to give information to the readers. According to Chesla (2001), the description is important because it can help to draw out our emotions by helping us imagine a 
situation. Description also deals with other kinds of perception although most of the description is about the visual experience.

Some previous research on reading comprehension problems revealed that reading ability is a fundamental issue that the majority of student face. According to Zuhra (2015), most EFL students failed to answer reading comprehension questions due to a lack of vocabulary and knowledge about the different types of reading comprehension questions. Her data, gathered through a questionnaire, revealed that the students' difficulties were due to a lack of inference knowledge. Another research has been conducted by Hidayati (2018) through a reading test and questionnaire as the instrument of data collection. The finding shows that finding the main idea, understanding vocabulary, poor mastery of grammar, understanding long sentences, and lack of knowledge of reading comprehension strategies were the most difficult aspects that the students encountered. Lastly, Adnyana (2017) found out that the majority of respondents have difficulty reading descriptive text due to a lack of vocabulary. This is due to students' lack of enthusiasm for learning as a result of the less varied learning method used. Furthermore, the students' worksheets that are used are less appealing and difficult for the students to understand.

This study became more intense as a result of the preceding theories about the importance of knowing the students' difficulties in reading to support the students' English mastery, as well as previous studies on the subject. It was crucial because the students' difficulties needed to be clarified in order to assist them with a suitable reading strategy.

\section{RESEARCH METHOD}

This research was conducted by applying descriptive research. Here, researcher intends to investigate and describes the present condition of research object based on the obtained factual data. As Nassaji (2015) explained that descriptive research seeks to describe a phenomenon and its characteristics. This study is more concerned with what happened rather than how or why it happened. The subject of this research was the Class XIIC students of SMPN 01 Sungai Raya Kabupaten Kubu Raya in Academic Year 2019/2020 which consists of 32 students.

A reading comprehension test was used to collect data, which was created in the form of multiple choice test. It consists of 20 questions related to the descriptive text with four options in each item. The item test for the students was divided into five 
aspects analysis of reading comprehension, which is labelled as the main idea, detailed information, vocabulary, inference and reference. The researcher attempted to determine whether or not the students could answer the test items by administering a reading comprehension test in the form of a multiple-choice test. The students' correct and incorrect answers were used to determine their level of difficulty especially in descriptive text. After computed the data, the result was specified into the criteria of mean score which classified from poor to excellent.

\section{FINDING AND DISCUSSION}

The result of the students reading comprehension test of descriptive text was ranged from $25-55$. The total score of the students' mean score in the reading comprehension test of descriptive text was 1640 .

$$
\begin{aligned}
X & =\frac{\sum x i}{N} \\
& =\frac{1485}{32} \\
& =46 \%
\end{aligned}
$$

Based on the computation of the students' mean score above, the students' reading comprehension in the descriptive text was $46 \%$ and categorized as poor to average. It means that the students have difficulties in reading comprehension especially on descriptive text. In order to know the detail of the students' difficulties in comprehending descriptive text, the researcher calculated the percentage of the students' right and wrong answers in each area of aspects analysis on reading comprehension. 


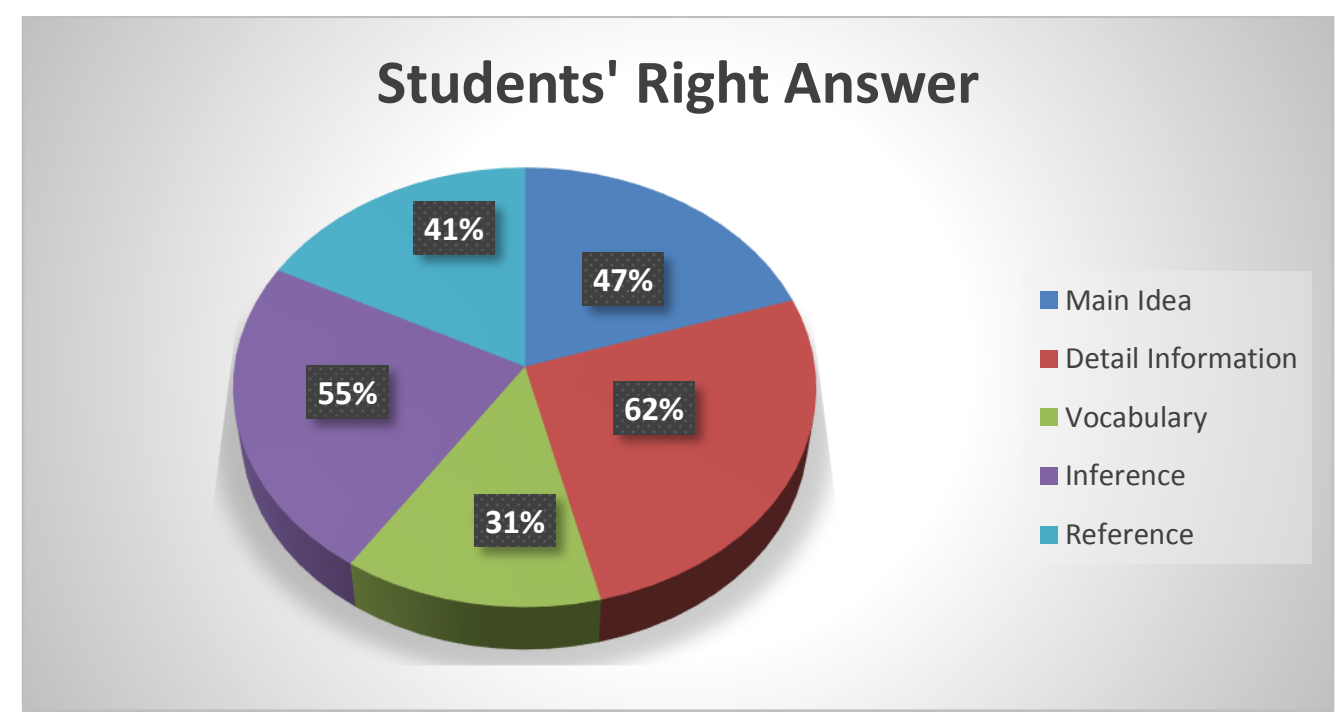

Figure 1. Students' Right Answer

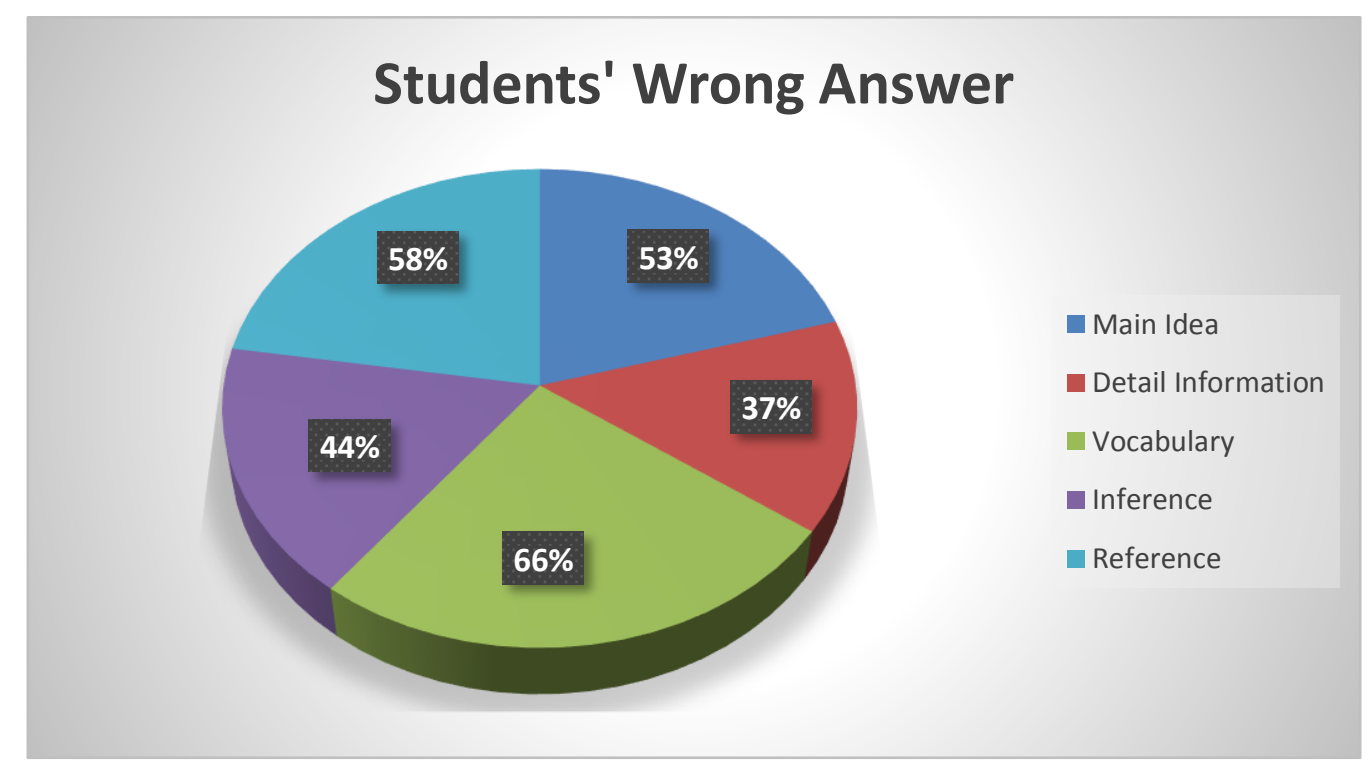

Figure 2. Students' Wrong Answer

Based on the above charts, it can be seen that the mean percentage of the students' right answers in comprehending the main idea, vocabulary and reference was lower than the percentage of students' wrong answers. It indicated that the students have difficulties in comprehending those aspects analysis of reading comprehension. Meanwhile, the mean percentage of the students' wrong answers to comprehend detailed information and inference was higher than the percentage of students' wrong answers. It indicated that the 
students do not have difficulties in comprehending those aspects analysis of reading comprehension.

Referring to the findings above, it can be concluded that the students have difficulties comprehending the descriptive text especially in comprehending the main idea, vocabulary and reference. The students' difficulties indicated by their wrong answers in completing the task given. There were as many as 53\% of students' wrong answers in comprehending the main idea, 66\% of students' wrong answers in comprehending vocabulary, and $58 \%$ of students' wrong answers in comprehending reference. Meanwhile, the total of the students' mean score in comprehending descriptive text was $46 \%$. As a general rule, students should have a success rate of approximately 80 percent. It means that the students' have not comprehended the descriptive text and have not achieved the standard level of comprehension. In other words, the students' have faced difficulties in comprehending descriptive text.

\section{CONCLUSION}

After analysed the result of the test, the researcher concluded through some important points of the findings. The ability of reading comprehension of descriptive text by the eighth-grade students categorized as poor based on the criteria of the mean score. The students have some difficulties in comprehending the main idea, vocabulary, and reference. To make the students understand the reading comprehension especially in descriptive text, the students are suggested to improve their reading comprehension of descriptive text by doing a lot of reading comprehension practice. Furthermore, the teacher who acts as a model to the students was suggested to give depth explanation about the aspects of reading comprehension in the descriptive text during the teaching-learning process.

\section{REFERENCES}

Adnyana, IGASW. (2017). Students' Difficulties in Comprehending Descriptive Texts: A Case Study at The Eleventh Grade Students of SMAN 7 Mataram in Academic Year 2017/2018. Mataram University.

Brown, H. D. (2003). Reading on Second Language Acquisition. New York: Longman.

Chesla E. (2001).8 Grade Reading Comprehension Success ( $1^{\text {st }}$ ed). New York: Learning Express, LLC. 
Harmer, J. (2007). The Practice of English Language Teaching (4 $\left.{ }^{\text {th }}\right)$. England: Pearson Education.

Hidayati, D. (2018). Students Difficulties in Reading Comprehension at the First Grade of SMAN 1 Darussalam Aceh Besar. Ar-Raniry State Islamic University.

Ismail, H., Syahruzah, J. K. \& Basuki. (2017). Improving the Students' Reading Skill through Translation Method. Journal of English Education (JEE), 2(2) 124-131.

Jarrah, H. \& Salina, N. (2018). Reading Comprehension Difficulties Among EFL Learners in Higher Learning Institutions. International Journal of English Linguistics, 8(7), 32-41.

McNamara, D. S. (2007). Reading Comprehension Strategies: Theories, Interventions, and Technologies. New York: Lawrence Erlbaum Associates.

Nassaji, H. (2015). Qualitative and descriptive research: Data type versus data analysis. Language Teaching Research, 19(2), 129-132.

Palani, K.K., 2012, 'Promoting reading habits and creating literate society', International Refereed Research Journal 3(2), 90-94.

Perangin-angin H. (2013). Improving Students'Reading Comprehension in Descriptive Text by Applying Prediction Strategy. Journal Outline.

Prihatini, S. O. (2020). An Analysis of Students' Difficulties in Reading Comprehension at SMA Negeri 1 Sukodadi Lamongan. E-Link Journal, 7(1), 21-29.

Prado, L., \& Plourde, L. (2005). Increasing reading comprehension through the explicit teaching of reading strategies: is there a difference among the genders?. Reading Improvement, 32-43.

Wardiman, A. Et all. (2008). English in Focus 2 for Grade VIII Junior High School. Surabaya: Depdiknas.

Zuhra. (2015). Senior High School Students' Difficulties in Reading Comprehension. English Education Journal (EEJ), 6(3), 424-44 